\title{
An Official American Thoracic Society/European Respiratory Society Policy Statement: Enhancing Implementation, Use, and Delivery of Pulmonary Rehabilitation
}

Carolyn L. Rochester, loannis Vogiatzis, Anne E. Holland, Suzanne C. Lareau, Darcy D. Marciniuk, Milo A. Puhan, Martijn A. Spruit, Sarah Masefield, Richard Casaburi, Enrico M. Clini, Rebecca Crouch, Judith Garcia-Aymerich, Chris Garvey, Roger S. Goldstein, Kylie Hill, Michael Morgan, Linda Nici, Fabio Pitta, Andrew L. Ries, Sally J. Singh, Thierry Troosters, Peter J. Wijkstra, Barbara P. Yawn, and Richard L. ZuWallack; on behalf of the ATS/ERS Task Force on Policy in Pulmonary Rehabilitation

This Official Policy Statement of the American Thoracic Society (ATS) and the European Respiratory Society (ERS) was approved by the ATS Board of Directors, October 2015, and by the ERS ScIence Councll, SePtember 2015

Rationale: Pulmonary rehabilitation (PR) has demonstrated physiological, symptom-reducing, psychosocial, and health economic benefits for patients with chronic respiratory diseases, yet it is underutilized worldwide. Insufficient funding, resources, and reimbursement; lack of healthcare professional, payer, and patient awareness and knowledge; and additional patient-related barriers all contribute to the gap between the knowledge of the science and benefits of PR and the actual delivery of PR services to suitable patients.

Objectives: The objectives of this document are to enhance implementation, use, and delivery of pulmonary rehabilitation to suitable individuals worldwide.

Methods: Members of the American Thoracic Society (ATS) Pulmonary Rehabilitation Assembly and the European Respiratory Society (ERS) Rehabilitation and Chronic Care Group established a Task Force and writing committee to develop a policy statement on PR. The document was modified based on feedback from expert peer reviewers. After cycles of review and revisions, the statement was reviewed and formally approved by the Board of Directors of the ATS and the Science Council and Executive Committee of the ERS.

Main Results: This document articulates policy recommendations for advancing healthcare professional, payer, and patient awareness and knowledge of PR, increasing patient access to PR, and ensuring quality of PR programs. It also recommends areas of future research to establish evidence to support the development of an updated funding and reimbursement policy regarding PR.

Conclusions: The ATS and ERS commit to undertake actions that will improve access to and delivery of PR services for suitable patients. They call on their members and other health professional societies, payers, patients, and patient advocacy groups to join in this commitment.

Keywords: pulmonary rehabilitation; policy; healthcare; chronic respiratory diseases; access

\section{Contents \\ Overview \\ Introduction \\ Methods}

Background: PR

Increasing Awareness and

Knowledge of PR

Healthcare Professional

Awareness and Knowledge

Payer Awareness and Knowledge
Patient Awareness and Knowledge

Increasing Patient Access to PR

Lack of Adequate PR

Infrastructure and Inadequate

Program Commissioning

Geographic Inaccessibility

Improving Access to PR for

Persons with Non-COPD

Respiratory Disorders
Limitations on PR Eligibility Based on COPD Disease Severity

Limitations on PR Eligibility over Time

Patient-Level Barriers to PR

Limited Number of PR

Healthcare Professionals

Ensuring Quality of PR Programs

Future Research To Advance

Evidence-based Policy in PR

ORCID ID: 0000-0002-6343-6050 (C.L.R.).

This article has an online supplement, which is accessible from this issue's table of contents at www.atsjournals.org

Am J Respir Crit Care Med Vol 192, Iss 11, pp 1373-1386, Dec 1, 2015

Copyright ( 2015 by the American Thoracic Society

DOI: 10.1164/rccm.201510-1966ST

Internet address: www.atsjournals.org 


\section{Overview}

Pulmonary rehabilitation (PR) is a "comprehensive intervention based on a thorough patient assessment followed by patient-tailored therapies that include, but are not limited to, exercise training, education, and behavior change, designed to improve the physical and psychological condition of people with chronic respiratory disease and to promote the long-term adherence to health-enhancing behaviors" (1). PR reduces patients' symptoms; improves limb muscle function, exercise capacity, emotional function, quality of life, knowledge, and self-efficacy; has health economic benefits (1-12); and is an essential component of the integrated care of patients with chronic respiratory diseases. However, despite its clear benefits, $\mathrm{PR}$ is grossly underutilized and is frequently inaccessible to patients. Insufficient funding; limited resources for PR programs; inadequate allocation of health system reimbursement for PR; lack of healthcare professional, payer, patient, and caregiver awareness and knowledge regarding the process and benefits of PR; suboptimal use of PR by suitable patients $(13,14)$; and limited training opportunities for PR professionals all contribute to the gap between the science and benefits of PR $(1,11,15)$ and the actual delivery of $\mathrm{PR}$ services.

Details of the science and delivery of PR were highlighted in the 2013 American Thoracic Society/European Respiratory Society Statement on PR (1). This new Policy Statement has a different focus: it provides policy recommendations with the principal objective of expanding the provision of PR to suitable individuals worldwide. It represents the consensus of international experts in the field of PR, experts in primary care, and international patient advocates. It provides recommendations that address key processes central to achieving our objectives of enhancing implementation, use, and delivery of $\mathrm{PR}$, including increasing healthcare professional, payer, and patient awareness and knowledge of PR; increasing patient access to PR; and ensuring quality of $\mathrm{PR}$ programs. It also provides suggestions for actionable items that will foster implementation of the policy recommendations. Noteworthy policy recommendations to increase implementation, use, and delivery of PR that are discussed in this statement include the following:

- Physician and allied healthcare professional trainees who treat patients with chronic respiratory diseases should have formal training in the science, process, and benefits of PR. Training requirements should be specified in national training curriculum documents, and consistency should be maintained in programs for each healthcare discipline and across disciplines.

- Physicians and other healthcare professionals in clinical practice should have educational opportunities in the process and benefits of PR consistent with evidence-based statements and guidelines.

- To increase payer awareness and knowledge of PR, healthcare professionals and patient advocacy groups should develop and disseminate information on the process, benefits, costs, and cost-effectiveness of PR to payers.

- To increase patient awareness and knowledge of PR, professional societies and patient advocacy and education experts should collaborate in the development of language, educationlevel, and culturally appropriate education materials in multiple formats for patients with chronic respiratory disease regarding the process and benefits of PR. Communication campaigns regarding $\mathrm{PR}$ should be addressed to the general public.

- Patient access to PR should be improved by augmenting program commissioning through increased sustainable payer funding, creating new PR programs in geographic areas where demand exceeds capacity, and developing and investigating novel PR program models that will make evidence-based PR more accessible and acceptable to patients and payers. Selection criteria for PR should reflect current published evidence.

- PR programs should follow relevant evidence-based clinical guidelines and demonstrate the measurement of standard outcomes to document benefits, quality, and safety.

- A core set of processes and outcomes should be established to enable national and international benchmarking in PR; this should include both process and performance metrics to enable recommendations for international standards based on evidence and best practice.

- Further research should be undertaken to advance evidence-based policy in PR, including further investigation regarding the cost-effectiveness of PR for chronic respiratory disorders, innovative models of PR delivery that will improve patients' access and uptake, and the barriers and facilitators of PR program referral, accessibility, enrollment, and adherence.

\section{Introduction}

Pulmonary rehabilitation (PR) has demonstrated physiological, symptomreducing, psychosocial, and health economic benefits in multiple outcome areas for patients with chronic respiratory diseases (1-8, 10-12, 15-49). As such, it should be a standard of care alongside other well-established treatments (such as pharmacotherapy, supplemental oxygen, or noninvasive ventilation) for patients with a chronic respiratory disease. Yet, PR remains grossly underutilized worldwide $(15,50)$; it is frequently not included in the integrated care of patients with chronic respiratory disorders and is often inaccessible to patients. Indeed, a substantial gap exists between knowledge regarding the science and benefits of $\mathrm{PR}$ $(11,12,15)$ and the actual delivery of PR services $(15,50)$. Reasons for this gap include: insufficient funding; limited resources for PR programs; inadequate allocation of health system reimbursement for PR; lack of healthcare professional, payer, patient, and caregiver awareness of and knowledge regarding the process and benefits of PR; suboptimal use of PR by suitable patients $(13,14)$; and limited training opportunities for PR professionals. These issues appear to be worldwide in scope (15). Importantly, also, although intensive inpatient rehabilitation services for the sickest patients are widely distributed, availability of outpatient or community-based PR programs is insufficient or lacking in many geographic areas. Moreover, within and among countries, $\mathrm{PR}$ is heterogeneous regarding program structure, content, staffing, available resources, and patient referral practices $(15,50,51)$. This heterogeneity has the potential to compound the issues 
listed above and to adversely affect the quality of programs.

This American Thoracic Society (ATS)/ European Respiratory Society (ERS) Policy Statement provides policy recommendations with the principal objective of expanding the provision of PR to suitable individuals. To this end, our goals are to:

1. Raise public and political awareness of the value and specific benefits of PR,

2. Trigger action by healthcare systems to provide adequate funding support for PR services and to include provision of $\mathrm{PR}$ in their strategic plans for care of respiratory diseases,

3. Increase healthcare professionals' prescription of $\mathrm{PR}$,

4. Enhance delivery of PR through increased program access and capacity,

5. Raise awareness of patients' experiences and barriers in accessing and attending PR,

6. Engage patients with chronic respiratory diseases and their caregivers to knowledgably request access to $\mathrm{PR}$,

7. Facilitate the development and implementation of quality metrics for the inclusion of PR into the integrated care of patients with a chronic respiratory disease,

8. Lay the groundwork for development of a process to implement the policy recommendations stated in this document.

Key processes central to achieving these objectives include: increasing healthcare professional, payer, and patient awareness and knowledge of PR; increasing patient access to $\mathrm{PR}$; and promoting quality $\mathrm{PR}$ programs. It is essential that program quality standards be met while maintaining cost efficiency to ensure optimal clinical outcomes for patients as well as sustainable funding of PR programs.

\section{Methods}

An ad hoc Task Force was formed, composed of experts from the ATS Pulmonary Rehabilitation Assembly, the ERS Rehabilitation and Chronic Care Group, the ATS and ERS Documents Development and Implementation Committees, representatives from the European Lung Foundation (ELF), and primary care representatives from the United States and Europe. An iterative consensus process was followed to develop this policy statement between May 2013 and January 2015. Informal surveys provided input from patients, patient advocacy groups (including the ATS Public Advisory Roundtable and ELF), insurance payers, as well as primary care and $\mathrm{PR}$ healthcare providers (see details of timeline and process in Table E1 in the online supplement). This policy statement was modified based on feedback from expert peer reviewers. After cycles of review and revisions, the statement was reviewed and formally approved by the Board of Directors of the ATS and the Science Council and Executive Committee of the ERS.

\section{Background: PR}

Patients with chronic respiratory diseases experience disabling symptoms (including dyspnea and fatigue) and exercise intolerance, have low physical activity levels, and report impaired quality of life $(4,52-62)$. The tremendous burden posed by these issues often persists despite optimal pharmacologic treatment.

Moreover, persons with respiratory diseases have heterogeneous features, and, for many, extrapulmonary manifestations such as skeletal muscle dysfunction (62-69) and medical and psychological comorbidities (such as anxiety and/or depression) are key contributors to their symptoms and functional limitations (70-73). PR, as defined in the 2013 Official ATS/ERS Statement, is "a comprehensive intervention based on a thorough patient assessment followed by patient-tailored therapies that include, but are not limited to, exercise training, education, and behavior change, designed to improve the physical and psychological condition of people with chronic respiratory disease and to promote the long-term adherence to health-enhancing behaviors" $(1,12)$. It emphasizes stabilization and/or reversal of extrapulmonary manifestations and comorbidities of chronic respiratory disease as well as the importance of behavior change. PR is an essential component of an integrated continuum of healthcare across the trajectory of the patient's illness as well as across healthcare providers and venues. It is not a new therapy; the first official ATS consensus statement on its application was published in 1981 (74). Major recent advances in the science and delivery of PR were highlighted in the 2013 ATS/ERS PR Statement $(1,12)$. The established benefits of PR are summarized in Table 1.

$\mathrm{PR}$ is beneficial throughout the course of disease for symptomatic medically stable patients with COPD (75) and other chronic respiratory disorders (11), and supervised, center-based PR is also effective during or soon after acute exacerbations of COPD $(76,77)$. Comprehensive PR has similar benefits when delivered in inpatient, outpatient, and community-based settings $(7,10,78,79)$. Generally, a minimum of 8 weeks (two to three sessions per week) of outpatient or community-based treatment (or comparable number of contact hours) is needed to achieve an effect on exercise performance and quality of life $(1,12,15$, $80)$; longer programs may produce greater gains $(12,80,81)$, and repeat courses yield benefits of equivalent magnitude to those of first-time participation (82). Exercise training is the cornerstone component of PR. Concurrent behavioral interventions, such as promoting self-efficacy and teaching collaborative self-management skills, are also integral to optimizing patient outcomes $(83,84)$. Patients graduating from a PR program stand to benefit from a home, community-based, or programbased maintenance exercise program to support the continuation of positive exercise behavior (85).

Table 1. Benefits of Pulmonary Rehabilitation (1-3, 5, 7, 10-12, 16-47, $49,63,140,141)$

- Reduced hospitalization

- Reduced unscheduled healthcare visits

- Improved exercise capacity

- Reduced symptoms of dyspnea and leg discomfort

- Improved limb muscle strength and endurance

- Improved health-related quality of life

- Improved functional capacity (e.g., activities of daily living)

- Improved emotional function

- Enhanced self-efficacy and knowledge

- Enhanced collaborative

self-management

- Potential for increased daily physical activity levels

Note: the order and degree of evidence for each of the above-noted benefits varies among chronic obstructive pulmonary disease and other respiratory diseases $(9,11)$. 
Table 2. Examples of Training Opportunities in Pulmonary Rehabilitation for Healthcare Professionals

- ERS HERMES program

- ATS and ERS postgraduate courses on PR (held periodically at annual international conferences)

- American College of Chest Physicians Annual Conference and specialty board review materials

- Lung Foundation Australia PR training Online

- Local courses in several countries (e.g., the UK, the Netherlands)

- Courses on PR promoted by respiratory societies in Latin America

Definition of abbreviations: ATS $=$ American Thoracic Society; ERS = European Respiratory Society; HERMES = Harmonised Education in

Respiratory Medicine for European Specialists; $\mathrm{PR}=$ pulmonary rehabilitation.

Lung Foundation Australia training online can be found at http://lungfoundation.com.au/

health-professionals/training-and-education/ pulmonary-rehabilitation-training-online/. HERMES education in Respiratory Medicine program of the ERS can be found at http://hermes.ersnet.org.

\section{Increasing Awareness and Knowledge of PR}

\section{Healthcare Professional Awareness and Knowledge}

Patients will not receive PR unless they are referred, which is unlikely to occur unless healthcare professionals (including primary care and specialist physicians, nurse practitioners, physician associates, and allied health professionals) are aware of the existence of PR and have knowledge of its benefits. Suboptimal healthcare professional awareness of PR is currently a barrier to patient referral (86).

Healthcare trainees. Awareness of $\mathrm{PR}$ should ideally begin during training. Currently, exposure to the processes, indications, and benefits of PR are generally not a mandatory part of the education of physicians, nurse practitioners, physician associates, or allied healthcare professionals. Although detailed recommendations for training in PR exist in some countries, such as the UK (87), even for pulmonary physicians, stated training requirements are often vague or limited. This is true in the United States (88), Canada (89), the Netherlands (90), Australia (91), and Latin America (92). Furthermore, primary care and other healthcare professionals, who provide care for the majority of patients with respiratory disease, often have very little if any exposure to PR in the course of their training. Some postgraduate training is available (Table 2), but it is not mandatory, is often not standardized, and is at the discretion of the healthcare professional. There is a clear need for enhanced and more standardized exposure to PR within existing healthcare professionals' training programs.

Healthcare professionals in clinical practice. There is a need for more education and learning opportunities for established practicing primary and specialty care physicians, nurse practitioners, physician associates, and other allied healthcare professionals about the process and benefits of PR. Increased knowledge of PR could foster dialogue between healthcare professionals and their patients, thereby promoting referrals to PR. Recommendations for increasing healthcare professional awareness and knowledge of PR are provided in Boxes 1 and 2.

\section{Payer Awareness and Knowledge}

$\mathrm{PR}$ is one of the most cost-effective treatment interventions available for patients with chronic respiratory diseases (93-97) and is associated with a substantial reduction in hospitalizations, other urgent healthcare resource use, and healthcare costs $(76,93-95,98,99)$. For example, its value is situated favorably within the context of other components of therapy for COPD in the UK (Figure 1) $(96,97)$; the relative value costs are not yet studied in non-COPD chronic respiratory disorders. Nevertheless, payer awareness of $\mathrm{PR}$ is often poor, and funding of $\mathrm{PR}$ is inadequate. Adequate funding is vital to $\mathrm{PR}$ program availability, capacity, effectiveness, and viability. Although heterogeneous payment structures and resources exist within and across countries (15), increasing payer knowledge is the first step toward securing adequate long-term funding.

Informal discussions with representatives from government and private insurance payers in several continents as part of development of this document suggested their perception that current funding and reimbursement for PR are adequate. However, the existence of payer-related barriers is supported by a published survey in the UK (93) and by an informal survey conducted by members of the Task Force for this document (Table E2). These surveys point to an inadequate appreciation among payers of the clinical effectiveness and cost-effectiveness of PR. To this end, increased dialogue and effective

\section{Box 1: Increasing Healthcare Professional Trainee Awareness and Knowledge of PR}

\section{Recommendations:}

- Physician and allied healthcare professional trainees who treat patients with chronic respiratory diseases should have core formal training in PR, including its scientific rationale, process, and benefits. This includes use of training modules covering the topics shown in Table 3 and provision of practical "hands-on" experiences.

- Training requirements should be specified in national training curriculum documents, and consistency should be maintained in programs for each healthcare discipline and across disciplines.

\section{Actionable Items:}

- Educational authorities from respiratory, primary care, nursing, and other allied healthcare professionals' societies collaborate to develop specific curricula for PR training for their respective healthcare trainees.

- Respiratory, primary care, and allied healthcare professionals' societies establish national training program curricular registries to coordinate and monitor progress toward curricula development. 
Table 3. Topics for Inclusion in Educational Materials for Healthcare Professionals

- The scientific rationale for PR

- Established benefits of PR

- Components of a multidisciplinary PR program

- Selection and referral of appropriate patients, including persons with non-COPD respiratory disorders

- Patient assessment and outcomes measurement techniques

- Program design and delivery in the context of local/regional resources

- Role of PR in the integrated care of patients with chronic respiratory diseases

- Importance of patients' long-term adherence to health-enhancing behaviors (such as physical activity, immunizations, abstinence from smoking) after PR: role of home caregivers and importance of coordinated care between healthcare professionals

- Opportunities for advanced care planning in the context of PR

- Relevant local, regional or national information regarding funding and payer reimbursement for $P R$

- Current gaps in access, barriers to patient participation in PR and potential solutions to these problems

Definition of abbreviations: COPD = chronic obstructive pulmonary disease; $\mathrm{PR}=$ pulmonary rehabilitation.

communication are needed between PR experts and providers, healthcare

professionals, professional societies (e.g., ATS, ERS, and others), payers, and health policy authorities regarding the established benefits and cost-effectiveness of PR as well as the priorities and concerns of payers.

Recommendations for increasing payer

\section{Box 2: Increasing Awareness and Knowledge of PR among Healthcare Professionals in Clinical Practice}

\section{Recommendation:}

- Physicians and other healthcare professionals in clinical practice should have educational opportunities in the process and benefits of PR consistent with evidence-based statements and guidelines.

\section{Actionable Items:}

- Primary care, specialty physician, and allied health professional societies partner with experts in PR to develop and implement more evidence-based, multiformat postgraduate educational programs on the process, benefits, and use of PR.

- Respiratory societies and national health authorities provide practical educational materials for clinicians (covering topics shown in Table 3) and a contact list of local PR programs in the clinic setting.

- Include PR in relevant professional learning offerings, such as scientific meetings and continuing medical education courses.

- Healthcare professionals document that PR was offered to suitable patients in clinical settings (including specification of the reasons for nonreferral) as a reflection of awareness and knowledge of its indications and benefits and to support quality metric assessment.

- Incorporate "clinical reminder alerts" for PR referral in electronic medical record systems.

awareness and knowledge of $\mathrm{PR}$ are provided in Box 3.

\section{Patient Awareness and Knowledge}

Patient uptake of PR and adherence to participation in $\mathrm{PR}$ are strikingly low $(5,13-15,41,50,100)$. Much of the responsibility for nonreferral to $\mathrm{PR}$ rests on healthcare professionals (7), but insufficient public awareness and knowledge of the process and health benefits of PR $(14,41)$ also prevent patients from seeking referral to and completion of a PR program.

Professional societies and patient advocacy groups can augment efforts to disseminate information and facilitate patient awareness of PR as a standard of care and to distinguish PR from chest physiotherapy. Increasing the awareness of PR among the general public is also essential. Relatives, friends, neighbors, coworkers, and others can encourage patients to seek out and participate in PR. Public awareness of PR may be enhanced through communication campaigns, including social media platforms (such as Facebook and YouTube). It is imperative that patients identified by evidence-based clinical management guidelines as having potential to benefit from PR are made aware of this therapy so that they can advocate for access to it through their regional and national

\section{Box 3: Increasing Payer Awareness and Knowledge of PR}

\section{Recommendations:}

- Healthcare professionals and patient advocacy groups should develop and disseminate information on the costs and cost-effectiveness of PR to payers.

- The process and outcomes of PR should be made more transparent to payers by PR service providers.

- Healthcare professionals should investigate the cost-effectiveness of PR in countries wherein this information is lacking.

\section{Actionable Items:}

Respiratory disease societies and PR providers, in collaboration with primary care health professional groups and patient advocacy groups:

- Develop methods of detailing the benefits, costs, and value of PR to be communicated to payers.

- Enhance platforms and assure increased resources for communicating the effectiveness of PR to payers.

- Develop a coordinated advocacy strategy to facilitate incorporation of PR into healthcare systems and practices as a "standard of care" component of the overall integrated care of patients with chronic respiratory diseases. 


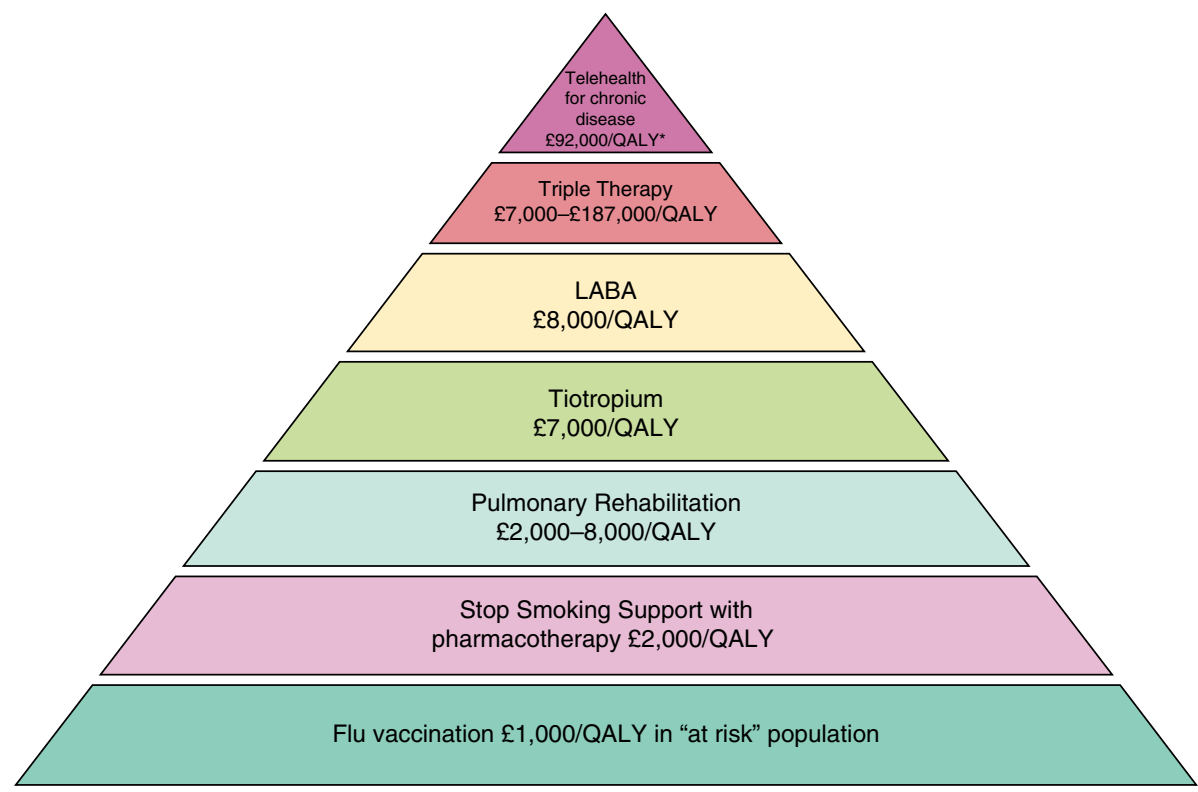

Figure 1. Cost-effectiveness of pulmonary rehabilitation relative to other treatments for chronic obstructive pulmonary disease. Reprinted from Reference 96. *Cost per quality-adjusted life year (QALY). LABA = long-acting $\beta$-agonist.

advocacy representatives.

Recommendations for increasing patient awareness and knowledge of $\mathrm{PR}$ are provided in Box 4.

\section{Increasing Patient Access to PR}

Variable access to PR creates unacceptable disparities in quality, evidencebased health care. Currently, there are exceeds the capacity of existing programs (4, 15). Capacity can be increased by creating new programs and/or by expanding existing programs. Both approaches will require significant buy-in, system change, and investment from healthcare professionals, healthcare policy-makers, administrators, and payers. This should be facilitated by demonstrating data showing return on investment for the local healthcare system and by providing policy advice for governments and nongovernmental organizations who advocate for people with chronic disease. Establishment of new PR programs and strategies to increase the capacity of existing PR programs must follow recommendations as detailed in the ATS/ERS PR Statement $(1,12)$ and other $\mathrm{PR}$ guidelines $(3,5,7,10)$. This includes adequate infrastructure (space for physical conditioning, exercise training, and monitoring equipment; resources for equipment maintenance and replacement; and space and resources for patient assessment and education), and staffing (number, training, experience, and competency [101]). The efficiency of programs also impacts capacity.

Measuring process metrics (such as time from patient referral to program uptake, and use of a central planning administrative structure for patient enrollment) is important in this regard. Expanding the range of program models delivered within existing comprehensive PR settings (e.g., outpatient or community based),

\section{Box 4: Increasing Patient Awareness and Knowledge of PR}

\section{Recommendations:}

- Professional societies and patient advocacy and education experts should collaborate in the development of language, education level, and culturally appropriate education materials in multiple formats (e.g., written, internet based) for patients with chronic respiratory diseases, to enable them to knowledgeably advocate for access to PR.

- Healthcare professionals should provide information regarding the process and benefits of PR to suitable patients.

- Communication campaigns should be addressed to the general public regarding the process and benefits of PR.

\section{Actionable Items:}

- Professional societies such as the ATS, ERS, and others partner with national and international patient advocacy groups to prepare and disseminate PR-related educational materials culturally adapted to each country and compatible with patient health literacy, and to ensure that educational messages are consistent in the materials for healthcare professionals, patients, and families.

- Professional societies such as the ATS and ERS and patient advocacy groups disseminate the above-noted educational materials to hospitals, clinics, community centers, and patient support groups and make them available online.

- Develop media campaigns with governmental and professional societies' support to increase the awareness of patients and the general public regarding the benefits of PR, exercise, and physical activity.

- PR providers within professional societies such as ATS and ERS advocate that pharmaceutical companies with access to patients spread awareness of the existence and benefits of PR in combination with other therapies (including pharmacotherapy and supplemental oxygen). 
adding PR as a treatment option within existing cardiac or general rehabilitation programs, or adding additional essential components of PR (besides exercise training that constitutes the cornerstone of every PR program), such as self-management training and patient education, to interventions composed solely of exercise training could also increase program capacity and patient access to PR. A significant increase in funding support for PR will be needed to address each of these issues.

\section{Geographic Inaccessibility}

Worldwide, access to PR is limited in many geographic areas, and in some countries PR programs are lacking altogether $(15,102)$. Patients frequently cite distance and lack of transportation as a major reason for poor program uptake or adherence (14). It is known that travel time greater than 30 minutes is a barrier to patient participation in PR (103). These factors should be considered when new PR programs are established.

\section{Improving Access to PR for Persons with Non-COPD Respiratory Disorders}

PR has demonstrated effectiveness for several respiratory conditions other than COPD $(2,11)$. Randomized controlled trials demonstrating its beneficial effects on exercise capacity, symptoms, and/or healthrelated quality of life are available in interstitial lung disease, bronchiectasis, asthma, cystic fibrosis, lung transplantation, lung cancer, and pulmonary hypertension (16-30, 32-34, 36, 38-40, 42, 43, 45, 46, 104). There may be special considerations and additional training for PR staff required when including persons with nonCOPD disorders $(3,11,12)$. Payer reimbursement of $\mathrm{PR}$ for non-COPD disorders remains limited in some countries. Payers and healthcare professionals require knowledge regarding appropriate patient selection criteria according to published evidence.

\section{Limitations on PR Eligibility Based on COPD Disease Severity}

Although PR benefits persons with many respiratory disorders, much of the published literature has, historically, centered on COPD. Provision of PR services for persons with COPD should be based on symptoms and functional status limitation rather than solely on the severity of lung function impairment $(1-3,6,10,12)$. PR effectively addresses several issues also experienced by persons with mild to moderate COPD, including exertional dyspnea (105-108), dynamic hyperinflation $(107,108)$, skeletal muscle dysfunction $(63,107$, 109), low physical activity levels (110, 111), depression (112), risk and impact of comorbidities such as cardiovascular disease (113), exacerbations of COPD (114), and impaired quality of life (115) (Table 1) (12). However, in some jurisdictions, access to $\mathrm{PR}$ is limited by regulations specifying insurance coverage of PR only for stable patients with COPD who have moderate to severe airflow obstruction. Such policies are not in line with strong evidence from randomized trials that show that both patients with unstable COPD who start rehabilitation during or after an exacerbations (76) and patients with stable mild to moderate COPD benefit from rehabilitation (116-118).

\section{Limitations on PR Eligibility over Time}

The benefits of 8 to 12 weeks of PR typically last up to 12 months $(17,21,119)$. Yet, patients live with their chronic respiratory diseases over the course of their lifetime. Emphasis is placed in PR programs on health-enhancing behavior change for this reason. Nevertheless, a nihilistic view toward PR is often taken by payers and healthcare professionals as a result of a potentially limited duration of the benefits resulting from patients' participation in a single PR program course. In some countries (e.g., the United States), there is a payer limit on the total number of PR sessions patients can attend. This is counterproductive, because repeat courses of PR afford similar benefits to those of initial patient participation (82) and, at least for COPD, PR is effective after acute disease exacerbations $(76,120)$, which are associated with worsened symptoms, functional decline, and high healthcare costs (121-123). Increasing patients' access to $\mathrm{PR}$, including repeated courses where clinically indicated, has the potential to improve patients' health over the course of their lives and to reduce healthcare use costs.

\section{Patient-Level Barriers to PR}

Patients referred to PR consistently report barriers to initiation of and adherence with the intervention $(13,14)$, and up to half of eligible patients referred to PR never attend (14). In addition to travel and transportation issues, lack of support from family members or other caregivers, depression, comorbid illness, and disruption of daily routine are particularly important (14). Members of the Task Force for this Policy Statement also conducted an informal survey of patients opinions regarding access to $\mathrm{PR}$ among members of ATS' Public Advisory Roundtable, ELF's patient organization network, the COPD Foundation, and the Pulmonary Fibrosis Foundation. Responses from patients with a wide variety of chronic respiratory conditions were included. Key patient-identified barriers to accessing PR identified in a survey of 1,686 respondents from 29 countries (Figure E1) included (in descending order of frequency) lack of awareness of PR ("never heard of it"), insufficient information on process or potential efficacy, lack of available PR services, and lack of insurance coverage. The findings of this patient survey corroborate the issues regarding awareness and knowledge of PR and access to PR discussed above. Importantly, many of these barriers seem modifiable with orchestrated actions.

\section{Limited Number of PR Healthcare Professionals}

Trained PR healthcare professionals are necessary for provision of PR to patients. Availability of education, training, and funding for healthcare professionals who strive to become PR providers varies within and across countries. Although formal documentation is lacking, insufficient availability of PR providers has the potential to limit patient access to PR.

Recommendations for increasing patient access to PR are provided in Box 5.

\section{Ensuring Quality of PR Programs}

The quality of PR programs is reflected in process and performance metrics. The 2013 ATS/ERS PR Statement, the 2013 British Thoracic Society quality standards, and other documents $(1,3,6,10,12,93,116$, 117) summarize the evidence underpinning best practice for PR. Program certification is a means of ensuring standards are met. 


\section{Box 5: Increasing Patient Access to PR}

\section{Recommendations:}

- Patient access to PR should be improved by augmenting program commissioning through increased sustainable payer funding.

- New PR programs should be created in geographic areas where demand exceeds capacity.

- Novel PR program models should be developed and studied that will make evidence-based PR more accessible and acceptable to patients and payers; this may include new approaches within hospital-based programs, community-based programs, comprehensive and wellresourced home-based or telehealth-supported programs, or other novel models of program delivery.

- Selection criteria for PR should reflect current published evidence. The evidence indicates that patients who benefit from PR include not only persons with moderate to severe airflow limitation but also those with mild to moderate airflow limitation with symptomlimited exercise tolerance, those after hospitalization for COPD exacerbation, and those with symptomatic non-COPD respiratory conditions. Increasing patient access for these patient groups will depend on increased referrals, increased payer funding, and patient demand for services.

\section{Actionable Items:}

- PR providers systematically detail and document the costs of providing comprehensive quality PR services and share this information with those advocating PR policies' reimbursement rate to facilitate appropriate and necessary reimbursement.

- Identify the number of patients potentially suitable for PR (based on outpatient and hospital discharge databases) within local and regional jurisdictions to assess the need for establishment of new PR programs and/or increased capacity of existing programs.

- PR providers, local funding agencies, health systems, patients, and researchers collaborate to establish the optimal models that will increase PR capacity and uptake.

- Professional societies (such as ATS, ERS, and others) audit existing patient selection criteria for PR and work with accreditation organizations to broaden patient candidacy to include those with symptomatic non-COPD respiratory conditions, those after hospitalization for COPD exacerbation, and symptomatic patients with mild to moderate airflow limitation.

- Professional respiratory societies (such as ATS, ERS, and others) audit the availability of PR providers and training programs for healthcare professionals who strive to become PR providers.

- Patients and their families partner with healthcare professionals, advocacy groups, and health professional societies to petition for greater capacity and access to PR in terms of the numbers of programs, patient eligibility, and insurance coverage.

- PR programs identify local barriers to patient uptake and adherence to PR and outline strategies to address these barriers.

- Payers offer incentives for suitable patients to participate in PR.

- Payers link healthcare professionals' patient referrals to PR to "pay for performance."

Currently, only the American Association of Cardiovascular and Pulmonary Rehabilitation (in the United States) (2) and some countries in Europe (124) offer this certification process. Implementation of a similar internationally relevant process that evaluates PR program quality and rewards quality programs is needed. This would facilitate highlighting and dissemination of quality standards for PR programs to healthcare facilities, healthcare professionals, and policy makers.

To qualify as PR, programs must include, at a minimum: a structured and supervised exercise program for patients with a variety of respiratory conditions, a patient education/ behavioral program intended to foster healthenhancing behavior, patient assessment and outcomes measures, and provision of recommendations for home-based exercise and physical activity $(1,3,5,7,10,12,93$, 125-128). Staff of PR programs must have demonstrated competencies in provision of PR (101). They must also be aware of and be prepared to work closely with other healthcare professionals to handle the multimorbidity present among persons referred for $\mathrm{PR}$, including the psychological impact and manifestations of chronic respiratory disease. To be universally applicable, these program components must be implemented with consideration of local resources, as well as cultural, economic, and healthcare system differences across countries. The health economic benefits of PR can potentially be further enhanced by using the program as a vehicle to promote increased daily physical activity, which may in turn reduce the risk of hospital admission (129).

The quality of PR programs is demonstrated by their success in improving patient outcomes. Patients entering PR programs are heterogeneous regarding disease state, symptoms, functional limitations, medical comorbidities, and psychologic burden of disease. Patient assessments conducted at the start of PR characterize patients to enable delivery of individualized rehabilitation according to each patient's needs. To assess program quality, clinical outcomes must be measured for individual patients and presented in aggregate. Essential outcomes measurements in PR include, at a minimum, the standardized assessment of patients' functional exercise capacity, dyspnea, and health status $(1-3,6,10,12)$. Several disease-relevant methods are available for measuring these outcomes $(11,12)$. Assessment of additional multidimensional outcomes (considered further in the 2013 ATS/ERS Statement on Pulmonary Rehabilitation) (1), including (but not limited to) impact of PR on psychological comorbidity and measures of the patient experience, is desirable, because patients' responses to $\mathrm{PR}$ are multidimensional (130). The selection and standardization of outcome measures for the purpose of program comparison and benchmarking will vary among different jurisdictions, but should be guided by the 


\section{Box 6: Ensuring Quality of PR Programs}

\section{Recommendations:}

- PR programs should follow relevant evidence-based clinical guidelines and demonstrate the measurement of standard outcomes, to document benefits, quality, and safety.

- A core set of processes and outcomes should be established to enable national and international benchmarking in PR; this should include both process and performance metrics to enable recommendations for international standards based on evidence and best practice.

- PR programs should encourage and foster patients' long-term adherence to health-enhancing behaviors to optimize patient wellness and reduce healthcare costs.

\section{Actionable Items:}

- National respiratory societies develop key performance and process indicators to assist in the process of program accreditation.

- Individual PR programs develop patient registries for purposes of monitoring program quality and outcomes.

- PR programs follow evidence-based clinical guidelines, including process, outcomes, quality, and safety, to justify reimbursement from payers.

- PR professionals within professional societies (such as ATS and ERS) collaborate to modify and expand existing national PR registries for international use.

respiratory scientific community based on disease-relevant published evidence.

Providers should be encouraged to quantify the economic benefits of patient participation in PR (e.g., reductions in hospital admissions) where possible.

Evidence of safety should be assessed based on standard operating policies, risk assessments, and critical incident reporting. PR program directors should conduct an annual internal audit of program process and outcomes. PR programs should also collect and respond to information on patient experience, needs, and satisfaction before, during, and after PR. Quality standards for PR should be consistent across programs, but solutions to achieve these standards must be appropriate to the locale, to ensure the best care of patients in a cost-effective manner.

Long-term adherence to healthenhancing behaviors, such as exercise, physical activity, abstinence from smoking, and immunization, is a key goal of PR. Although the optimal means of maintaining benefits achieved in PR is not fully clear (85, 131), PR professionals' efforts to assist patients in continuing to adhere to exercise, incorporating knowledge gained in PR into daily living, and maintaining collaborative interaction with healthcare professionals over the long term are essential.

Involvement of home caregivers and close collaboration and coordination of care between patients, PR professionals, and patients' other healthcare providers are crucial to achieve these goals.

Recommendations for ensuring quality of $\mathrm{PR}$ programs are provided in Box 6 .

\section{Future Research To Advance Evidence-based Policy in PR}

Although the scientific rationale for PR is established, and the evidence of the benefits

\section{Box 7: Future Research to Advance Evidence-based Policy in PR}

\section{Recommendations:}

- Further research should be undertaken regarding the cost-effectiveness of PR: this may include innovative models of PR delivery, sites and/or timing of PR, PR for respiratory disorders other than COPD, and repeat courses of PR over time.

- Further investigation of alternative models of providing PR should be undertaken to improve access and uptake, using program models of known efficacy.

- Further investigation of alternative models of providing PR should be undertaken to address the needs of patients with a high burden of psychological and multiple medical comorbidities.

- Further research should be done regarding barriers and facilitators of PR program referrals, accessibility, enrollment, and adherence for persons with chronic respiratory diseases.

- Further research should be undertaken to assess the impact of PR program funding source on patient use of PR.

\section{Actionable Items:}

- PR experts articulate and document priorities for PR-related research within PR assemblies of professional organizations such as ATS and ERS and communicate them to patient advocacy groups and funding agencies via stakeholder forums and workshops.

- PR experts lobby professional societies as well as patient advocacy organizations and federal agencies to direct current and future funding toward PR research.

- Healthcare professionals conduct pragmatic, "real-world" trials of PR. 
of PR for persons with COPD and other forms of chronic respiratory disease is extensive and convincing, there are several areas wherein further knowledge is needed (Table E3) (12). Importantly, the Task Force for this Policy Statement identifies key areas for future research that will

impact commissioning policy for PR and will in turn have potential to augment delivery of $\mathrm{PR}$ services and patient access to PR.

Although the traditional models of inpatient and outpatient PR are suitable for many patients, alternative models may also be effective and may improve patient access, particularly in regions or healthcare systems where traditional models of PR are not feasible. For example, tele-rehabilitation, which links expert rehabilitation healthcare providers with others at a remote site or with patients in their homes, also has potential to improve access. Initial small-scale studies demonstrate feasibility and suggest that clinical benefits may be achieved (132-135). Carefully structured home-based exercise training and rehabilitation that is supported by $\mathrm{PR}$ program staff with or without specialized exercise equipment might be feasible in some healthcare environments $(136,137)$. Alternate methods for components of exercise training (such as use of elastic resistance tubes rather than specialized equipment for resistance training) (138) may be applicable across a broad range of settings. Robust research is underway in these areas (139), and further work is needed to validate these approaches. Adoption of alternative models for PR will require demonstration of comparable or greater clinical outcomes to those of traditional PR programs, as well as evaluation of safety and cost-effectiveness, staff training, and guideline development. Thus, to move the field forward, more funding for PR research in these areas will be needed.

More information is also needed regarding the clinical and economic benefits of repeat courses of PR (especially for patients with chronic respiratory disorders other than COPD) and regarding optimal strategies for managing medical and psychological multimorbidity in the context of PR. Also, although the impact of funding source on patient use of $\mathrm{PR}$ is unclear, sources of funding for PR programs and reimbursement for patient participation vary widely, and this may in turn impact patient enrollment and participation (15). Young healthcare professionals will also require encouragement and an increase in infrastructure to enable them to pursue careers as clinician investigators with a focus on PR. Recommendations for future research to advance evidence-based policy in PR are provided in Box 7.

\section{This Policy Statement was prepared by the ATS/ERS Task Force on Policy in Pulmonary Rehabilitation.}

\section{Members of the task force are as follows:}

Carolyn L. Rochester, M.D. (Co-Chair)

Ioannis Vogiatzis, Ph.D. (Co-Chair)

Richard L. ZuWALlaCK, M.D.

Milo A. Puhan, M.D., Ph.D.

Darcy D. Marciniuk, M.D.

Anne E. Holland, B.Sc. (Physiotherapy), Ph.D.

SuZanne C. Lareau, R.N., M.S.

Martijn A. Spruit, P.T., Ph.D.

ANDREW L. Ries, M.D., M.P.H.

Michael Morgan, M.D., Ph.D.

Roger S. Goldstein, M.B.ChB.

ENRICO M. CLINI, M.D.

LiNDA NicI, M.D.

Thierry Troosters, P.T., Ph.D.
Sally J. Singh, Ph.D.

Richard Casaburi, Ph.D., M.D.

Chris Garvey, F.N.P., M.S.N., M.P.A.

Barbara P. YaWn, M.D., MSc.

Fabio Pitta, P.T., Ph.D.

Kylie Hill, B.Sc. (Physiotherapy), Ph.D.

Rebecca Crouch, P.T., D.P.T., M.S.

Judith Garcia-Aymerich, M.D., Ph.D.

Peter J. Wijkstra, M.D., Ph.D.

Sarah Masefield (ELF)

Pippa Powell $(\mathrm{ELF})^{1}$

BJorn STAHLberg, M.D. ${ }^{1}$

${ }^{1}$ These individuals were members of the task force but were not members of the writing committee.

\begin{abstract}
Author Disclosures: C.L.R. served on an advisory committee of GlaxoSmithKline. S.C.L. served on an advisory committee of Boehringer Ingelheim. D.D.M. is a board member of the Lung Health Institute of Canada. M.A.S. received relevant financial support from $\mathrm{CIRO}+$ in the Netherlands and REVAL/BIOMED in Belgium. M.M. is the National Clinical Director for Respiratory Services for NHS England. P.J.W. served as a speaker for Philips/ Respironics, ResMed, and VIVISOL and received research support paid to his institution from ResMed, VIVISOL, and VitalAire-Air Liquide. I.V., A.E.H., M.A.P., S.M., R. Casaburi, E.M.C., R. Crouch, J.G.-A., C.G., R.S.G., K.H., L.N., F.P., A.L.R., S.J.S., T.T. B.P.Y., and R.L.Z. reported no relevant commercial relationships.
\end{abstract}

\section{References}

1. Spruit MA, Singh SJ, Garvey C, ZuWallack R, Nici L, Rochester C, Hill K, Holland AE, Lareau SC, Man WD, et al.; ATS/ERS Task Force on Pulmonary Rehabilitation. An official American Thoracic Society/ European Respiratory Society statement: key concepts and advances in pulmonary rehabilitation. Am J Respir Crit Care Med 2013;188:e13-e64.

2. American Association of Cardiovascular and Pulmonary Rehabilitation. Guidelines for cardiac rehabilitation and secondary prevention programs. Champaign, IL, Human Kinetics; 2011.

3. Bolton CE, Bevan-Smith EF, Blakey JD, Crowe P, Elkin SL, Garrod R, Greening NJ, Heslop K, Hull JH, Man WD, et al.; British Thoracic Society Pulmonary Rehabilitation Guideline Development Group; British Thoracic Society Standards of Care Committee. British Thoracic Society guideline on pulmonary rehabilitation in adults. Thorax 2013;68:ii1-ii30.

4. Global Initiative for Chronic Obstructive Lung Disease (GOLD). Gobal strategy for the diagnosis, management, and prevention of COPD. United States; 2014 [accessed 2015 Oct 26]. Available from: http:// www.goldcopd.org/uploads/users/files/GOLD_Report_2013_Feb20.pdf
5. Marciniuk DD, Brooks D, Butcher S, Debigare R, Dechman G, Ford G, Pepin V, Reid D, Sheel AW, Stickland MK, et al. Optimizing pulmonary rehabilitation in chronic obstructive pulmonary disease-practical issues: a Canadian Thoracic Society Clinical Practice Guideline. Can Respir J 2010;17:159-168.

6. Marciniuk DD, Goodridge D, Hernandez P, Rocker G, Balter M, Bailey P, Ford G, Bourbeau J, O'Donnell DE, Maltais F, et al. Managing dyspnea in patients with advanced chronic obstructive pulmonary disease: a Canadian Thoracic Society Clinical Practice Guideline. Can Respir J 2011;18:69-78.

7. Nici L, Donner C, Wouters E, Zuwallack R, Ambrosino N, Bourbeau J, Carone M, Celli B, Engelen M, Fahy B, et al.; ATS/ERS Pulmonary Rehabilitation Writing Committee. American Thoracic Society/ European Respiratory Society statement on pulmonary rehabilitation. Am J Respir Crit Care Med 2006;173:1390-1413.

8. O'Donnell DE, Aaron S, Bourbeau J, Hernandez P, Marciniuk DD, Balter M, Ford G, Gervais A, Goldstein R, Hodder R, et al. Canadian Thoracic Society recommendations for management of chronic obstructive pulmonary disease: 2007 update. Can Respir J 2007;14:5B-32B.

9. Puhan MA, Lareau SC. Evidence-based outcomes from pulmonary rehabilitation in the chronic obstructive pulmonary disease patient. Clin Chest Med 2014;35:295-301. 
10. Ries AL, Bauldoff GS, Carlin BW, Casaburi R, Emery CF, Mahler DA, Make B, Rochester CL, Zuwallack R, Herrerias C. Pulmonary rehabilitation: joint ACCP/AACVPR evidence-based clinical practice guidelines. Chest 2007;131:4S-42S.

11. Rochester C, Fairburn C, Crouch R. Pulmonary rehabilitation for disorders other than chronic obstructive pulmonary disease. Clin Chest Med 2014;35:369-389.

12. Singh SJ, ZuWallack RL, Garvey C, Spruit MA; American Thoracic Society/European Respiratory Society Task Force on Pulmonary Rehabilitation. Learn from the past and create the future: the 2013 ATS/ERS statement on pulmonary rehabilitation. Eur Respir J 2013; 42:1169-1174.

13. Jones SE, Green SA, Clark AL, Dickson MJ, Nolan AM, Moloney C, Kon SS, Kamal F, Godden J, Howe C, et al. Pulmonary rehabilitation following hospitalisation for acute exacerbation of COPD: referrals, uptake and adherence. Thorax 2014;69:181-182.

14. Keating A, Lee A, Holland AE. What prevents people with chronic obstructive pulmonary disease from attending pulmonary rehabilitation? A systematic review. Chron Respir Dis 2011;8:89-99.

15. Spruit MA, Pitta F, Garvey C, ZuWallack RL, Roberts CM, Collins EG, Goldstein R, McNamara R, Surpas P, Atsuyoshi K, et al.; ERS Rehabilitation and Chronic Care, and Physiotherapists Scientific Groups; American Association of Cardiovascular and Pulmonary Rehabilitation; ATS Pulmonary Rehabilitation Assembly and the ERS COPD Audit team. Differences in content and organisational aspects of pulmonary rehabilitation programmes. Eur Respir J 2014;43:1326-1337.

16. Gloeckl R, Halle M, Kenn K. Interval versus continuous training in lung transplant candidates: a randomized trial. $J$ Heart Lung Transplant 2012;31:934-941.

17. Holland AE, Hill CJ, Conron M, Munro P, McDonald CF. Short term improvement in exercise capacity and symptoms following exercise training in interstitial lung disease. Thorax 2008;63:549-554.

18. Jones LW, Eves ND, Kraus WE, Potti A, Crawford J, Blumenthal JA, Peterson BL, Douglas PS. The lung cancer exercise training study: a randomized trial of aerobic training, resistance training, or both in postsurgical lung cancer patients: rationale and design. BMC Cancer 2010;10:155.

19. Klijn PH, Oudshoorn A, van der Ent CK, van der Net J, Kimpen JL, Helders PJ. Effects of anaerobic training in children with cystic fibrosis: a randomized controlled study. Chest 2004;125:1299-1305.

20. Mendes FA, Gonçalves RC, Nunes MP, Saraiva-Romanholo BM, Cukier A, Stelmach R, Jacob-Filho W, Martins MA, Carvalho CR. Effects of aerobic training on psychosocial morbidity and symptoms in patients with asthma: a randomized clinical trial. Chest 2010;138: 331-337.

21. Mereles D, Ehlken N, Kreuscher S, Ghofrani S, Hoeper MM, Halank M, Meyer FJ, Karger G, Buss J, Juenger J, et al. Exercise and respiratory training improve exercise capacity and quality of life in patients with severe chronic pulmonary hypertension. Circulation 2006;114: 1482-1489.

22. Moorcroft AJ, Dodd ME, Morris J, Webb AK. Individualised unsupervised exercise training in adults with cystic fibrosis: a 1 year randomised controlled trial. Thorax 2004;59: 1074-1080.

23. Newall C, Stockley RA, Hill SL. Exercise training and inspiratory muscle training in patients with bronchiectasis. Thorax 2005;60: 943-948.

24. Nishiyama O, Kondoh Y, Kimura T, Kato K, Kataoka K, Ogawa T, Watanabe F, Arizono S, Nishimura K, Taniguchi H. Effects of pulmonary rehabilitation in patients with idiopathic pulmonary fibrosis. Respirology 2008;13:394-399.

25. Schneiderman-Walker J, Pollock SL, Corey M, Wilkes DD, Canny GJ, Pedder L, Reisman JJ. A randomized controlled trial of a 3-year home exercise program in cystic fibrosis. J Pediatr 2000;136: 304-310.

26. Selvadurai HC, Blimkie CJ, Meyers N, Mellis CM, Cooper PJ, Van Asperen PP. Randomized controlled study of in-hospital exercise training programs in children with cystic fibrosis. Pediatr Pulmonol 2002;33:194-200.
27. Turner S, Eastwood P, Cook A, Jenkins S. Improvements in symptoms and quality of life following exercise training in older adults with moderate/severe persistent asthma. Respiration 2011;81:302-310.

28. Bradley J, Moran F. Physical training for cystic fibrosis. Cochrane Database Syst Rev 2008;1:CD002768.

29. Carson KV, Chandratilleke MG, Picot J, Brinn MP, Esterman AJ, Smith BJ. Physical training for asthma. Cochrane Database Syst Rev 2013; 9:CD001116

30. Chan L, Chin LM, Kennedy M, Woolstenhulme JG, Nathan SD, Weinstein AA, Connors G, Weir NA, Drinkard B, Lamberti J, et al. Benefits of intensive treadmill exercise training on cardiorespiratory function and quality of life in patients with pulmonary hypertension. Chest 2013;143:333-343.

31. de Man FS, Handoko ML, Groepenhoff H, van 't Hul AJ, Abbink J, Koppers RJ, Grotjohan HP, Twisk JW, Bogaard HJ, Boonstra A, et al. Effects of exercise training in patients with idiopathic pulmonary arterial hypertension. Eur Respir J 2009;34:669-675.

32. Dowman L, Hill CJ, Holland AE. Pulmonary rehabilitation for interstitial lung disease. Cochrane Database Syst Rev 2014;10: CD006322.

33. Edvardsen E, Skjønsberg OH, Holme I, Nordsletten L, Borchsenius F, Anderssen SA. High-intensity training following lung cancer surgery: a randomised controlled trial. Thorax 2015;70:244-250.

34. Granger CL, Chao C, McDonald CF, Berney S, Denehy L. Safety and feasibility of an exercise intervention for patients following lung resection: a pilot randomized controlled trial. Integr Cancer Ther 2013;12:213-224.

35. Grünig E, Lichtblau M, Ehlken N, Ghofrani HA, Reichenberger F, Staehler G, Halank M, Fischer C, Seyfarth HJ, Klose H, et al. Safety and efficacy of exercise training in various forms of pulmonary hypertension. Eur Respir J 2012;40:84-92.

36. Hebestreit $H$, Kieser $S$, Junge $S$, Ballmann M, Hebestreit $A$, Schindler C, Schenk T, Posselt HG, Kriemler S. Long-term effects of a partially supervised conditioning programme in cystic fibrosis. Eur Respir $J$ 2010;35:578-583.

37. Hwang CL, Yu CJ, Shih JY, Yang PC, Wu YT. Effects of exercise training on exercise capacity in patients with non-small cell lung cancer receiving targeted therapy. Support Care Cancer 2012;20: 3169-3177.

38. Kriemler S, Kieser S, Junge S, Ballmann M, Hebestreit A, Schindler C, Stussi C, Hebestreit $\mathrm{H}$. Effect of supervised training on FEV1 in cystic fibrosis: a randomised controlled trial. J Cyst Fibros 2013;12: 714-720.

39. Langer D, Burtin C, Schepers L, Ivanova A, Verleden G, Decramer M, Troosters T, Gosselink R. Exercise training after lung transplantation improves participation in daily activity: a randomized controlled trial. Am J Transplant 2012;12:1584-1592.

40. Lee AL, Hill CJ, Cecins N, Jenkins S, McDonald CF, Burge AT, Rautela L, Stirling RG, Thompson PJ, Holland AE. The short and long term effects of exercise training in non-cystic fibrosis bronchiectasis: a randomised controlled trial. Respir Res 2014;15:44.

41. Hayton C, Clark A, Olive S, Browne P, Galey P, Knights E, Staunton L, Jones A, Coombes E, Wilson AM. Barriers to pulmonary rehabilitation: characteristics that predict patient attendance and adherence. Respir Med 2013;107:401-407.

42. Mandal P, Sidhu MK, Kope L, Pollock W, Stevenson LM, Pentland JL, Turnbull K, Mac Quarrie S, Hill AT. A pilot study of pulmonary rehabilitation and chest physiotherapy versus chest physiotherapy alone in bronchiectasis. Respir Med 2012;106:1647-1654.

43. Morano MT, Araújo AS, Nascimento FB, da Silva GF, Mesquita R, Pinto JS, de Moraes Filho MO, Pereira ED. Preoperative pulmonary rehabilitation versus chest physical therapy in patients undergoing lung cancer resection: a pilot randomized controlled trial. Arch Phys Med Rehabil 2013;94:53-58.

44. Ochmann U, Kotschy-Lang N, Raab W, Kellberger J, Nowak D, Jorres RA. Long-term efficacy of pulmonary rehabilitation in patients with occupational respiratory diseases. Respiration 2012;84: 396-405.

45. Stefanelli F, Meoli I, Cobuccio R, Curcio C, Amore D, Casazza D, Tracey M, Rocco G. High-intensity training and cardiopulmonary exercise testing in patients with chronic obstructive pulmonary 
disease and non-small-cell lung cancer undergoing lobectomy. Eur $J$ Cardiothorac Surg 2013;44:e260-e265.

46. Stigt JA, Uil SM, van Riesen SJ, Simons FJ, Denekamp M, Shahin GM, Groen HJ. A randomized controlled trial of postthoracotomy pulmonary rehabilitation in patients with resectable lung cancer. $J$ Thorac Oncol 2013;8:214-221.

47. Swigris JJ, Fairclough DL, Morrison M, Make B, Kozora E, Brown KK, Wamboldt FS. Benefits of pulmonary rehabilitation in idiopathic pulmonary fibrosis. Respir Care 2011;56:783-789.

48. Ley S, Fink C, Risse F, Ehlken N, Fischer C, Ley-Zaporozhan J, Kauczor $\mathrm{HU}$, Klose H, Gruenig E. Magnetic resonance imaging to assess the effect of exercise training on pulmonary perfusion and blood flow in patients with pulmonary hypertension. Eur Radiol 2013;23:324-331.

49. Mainguy V, Maltais F, Saey D, Gagnon P, Martel S, Simon M, Provencher $\mathrm{S}$. Effects of a rehabilitation program on skeletal muscle function in idiopathic pulmonary arterial hypertension. $J$ Cardiopulm Rehabil Prev 2010;30:319-323.

50. Garvey C, Fullwood MD, Rigler J. Pulmonary rehabilitation exercise prescription in chronic obstructive lung disease: US survey and review of guidelines and clinical practices. J Cardiopulm Rehabil Prev 2013;33:314-322.

51. Desveaux L, Janaudis-Ferreira T, Goldstein R, Brooks D. An international comparison of pulmonary rehabilitation: a systematic review. COPD 2015;12:144-153.

52. Bajwah S, Higginson IJ, Ross JR, Wells AU, Birring SS, Riley J, Koffman J. The palliative care needs for fibrotic interstitial lung disease: a qualitative study of patients, informal caregivers and health professionals. Palliat Med 2013;27: 869-876.

53. Guillevin L, Armstrong I, Aldrighetti R, Howard LS, Ryftenius H, Fischer A, Lombardi S, Studer S, Ferrari P. Understanding the impact of pulmonary arterial hypertension on patients' and carers' lives. Eur Respir Rev 2013;22:535-542.

54. Hebestreit H, Schmid K, Kieser S, Junge S, Ballmann M, Roth $\mathrm{K}$, Hebestreit A, Schenk T, Schindler C, Posselt HG, et al. Quality of life is associated with physical activity and fitness in cystic fibrosis. $B M C$ Pulm Med 2014;14:26.

55. Mainguy V, Provencher S, Maltais F, Malenfant S, Saey D. Assessment of daily life physical activities in pulmonary arterial hypertension. Plos One 2011;6:e27993.

56. Mancuso CA, Choi TN, Westermann H, Wenderoth S, Wells MT, Charlson ME. Improvement in asthma quality of life in patients enrolled in a prospective study to increase lifestyle physical activity. J Asthma 2013;50:103-107.

57. Mendes FA, Lunardi AC, Silva RA, Cukier A, Stelmach R, Martins MA, Carvalho CR. Association between maximal aerobic capacity and psychosocial factors in adults with moderate-to-severe asthma. $J$ Asthma 2013;50:595-599.

58. Miyamoto S, Nagaya N, Satoh T, Kyotani S, Sakamaki F, Fujita M, Nakanishi N, Miyatake K. Clinical correlates and prognostic significance of six-minute walk test in patients with primary pulmonary hypertension: comparison with cardiopulmonary exercise testing. Am J Respir Crit Care Med 2000;161:487-492.

59. Myrdal G, Valtysdottir S, Lambe M, Ståhle E. Quality of life following lung cancer surgery. Thorax 2003;58:194-197.

60. Novoa N, Varela G, Jiménez MF, Aranda JL. Influence of major pulmonary resection on postoperative daily ambulatory activity of the patients. Interact Cardiovasc Thorac Surg 2009;9:934-938.

61. Ostroff JS, Krebs P, Coups EJ, Burkhalter JE, Feinstein MB, Steingart RM, Logue AE, Park BJ. Health-related quality of life among earlystage, non-small cell, lung cancer survivors. Lung Cancer 2011;71: 103-108.

62. Troosters T, Langer D, Vrijsen B, Segers J, Wouters K, Janssens W, Gosselink R, Decramer M, Dupont L. Skeletal muscle weakness, exercise tolerance and physical activity in adults with cystic fibrosis. Eur Respir J 2009;33:99-106.

63. Maltais F, Decramer M, Casaburi R, Barreiro E, Burelle $Y$, Debigaré R, Dekhuijzen PN, Franssen F, Gayan-Ramirez G, Gea J, et al.; ATS/ ERS Ad Hoc Committee on Limb Muscle Dysfunction in COPD. An official American Thoracic Society/European Respiratory
Society statement: update on limb muscle dysfunction in chronic obstructive pulmonary disease. Am J Respir Crit Care Med 2014; 189:e15-e62.

64. Breda AP, Pereira de Albuquerque AL, Jardim C, Morinaga LK, Suesada MM, Fernandes CJ, Dias B, Lourenço RB, Salge JM, Souza R. Skeletal muscle abnormalities in pulmonary arterial hypertension. Plos One 2014;9:e114101.

65. Mainguy V, Maltais F, Saey D, Gagnon P, Martel S, Simon M, Provencher S. Peripheral muscle dysfunction in idiopathic pulmonary arterial hypertension. Thorax 2010;65:113-117.

66. Nishiyama O, Taniguchi H, Kondoh Y, Kimura T, Ogawa T, Watanabe F, Arizono S. Quadriceps weakness is related to exercise capacity in idiopathic pulmonary fibrosis. Chest 2005; 127:2028-2033.

67. Ozalp O, Inal-Ince D, Calik E, Vardar-Yagli N, Saglam M, Savci S, Arikan H, Bosnak-Guclu M, Coplu L. Extrapulmonary features of bronchiectasis: muscle function, exercise capacity, fatigue, and health status. Multidiscip Respir Med 2012;7:3.

68. Walsh JR, Chambers DC, Davis RJ, Morris NR, Seale HE, Yerkovich ST, Hopkins PM. Impaired exercise capacity after lung transplantation is related to delayed recovery of muscle strength. Clin Transplant 2013;27:E504-E511.

69. Wang XN, Williams TJ, McKenna MJ, Li JL, Fraser SF, Side EA, Snell GI, Walters EH, Carey MF. Skeletal muscle oxidative capacity, fiber type, and metabolites after lung transplantation. Am J Respir Crit Care Med 1999;160:57-63.

70. Löwe B, Gräfe K, Ufer C, Kroenke K, Grünig E, Herzog W, Borst MM Anxiety and depression in patients with pulmonary hypertension. Psychosom Med 2004;66:831-836.

71. Paz-Díaz H, Montes de Oca M, López JM, Celli BR. Pulmonary rehabilitation improves depression, anxiety, dyspnea and health status in patients with COPD. Am J Phys Med Rehabil 2007;86: 30-36.

72. Ryerson CJ, Berkeley J, Carrieri-Kohlman VL, Pantilat SZ, Landefeld CS, Collard HR. Depression and functional status are strongly associated with dyspnea in interstitial lung disease. Chest 2011;139: 609-616.

73. White J, Hopkins RO, Glissmeyer EW, Kitterman N, Elliott CG. Cognitive, emotional, and quality of life outcomes in patients with pulmonary arterial hypertension. Respir Res 2006;7:55.

74. Hodgkin JE, Farrell MJ, Gibson SR, Kanner RE, Kass I, Lampton LM, Nield M, Petty TL. American Thoracic Society. Medical section of the American Lung Association. Pulmonary rehabilitation. Am Rev Respir Dis 1981;124:663-666.

75. Spruit MA, Pennings HJ, Janssen PP, Does JD, Scroyen S, Akkermans MA, Mostert R, Wouters EF. Extra-pulmonary features in COPD patients entering rehabilitation after stratification for MRC dyspnea grade. Respir Med 2007;101:2454-2463.

76. Puhan MA, Gimeno-Santos E, Scharplatz M, Troosters T, Walters EH, Steurer J. Pulmonary rehabilitation following exacerbations of chronic obstructive pulmonary disease. Cochrane Database Syst Rev 2011;10:CD005305.

77. Criner GJ, Bourbeau J, Diekemper RL, Ouellette DR, Goodridge D, Hernandez P, Curren K, Balter MS, Bhutani M, Camp PG, et al. Prevention of acute exacerbations of chronic obstructive pulmonary disease: American College of Chest Physicians and Canadian Thoracic Society guideline. Chest 2015;147:894-942.

78. Clini E, Foglio K, Bianchi L, Porta R, Vitacca M, Ambrosino N. Inhospital short-term training program for patients with chronic airway obstruction. Chest 2001;120:1500-1505.

79. Wootton SL, Ng LW, McKeough ZJ, Jenkins S, Hill K, Eastwood PR, Hillman DR, Cecins N, Spencer LM, Jenkins C, et al. Ground-based walking training improves quality of life and exercise capacity in COPD. Eur Respir J 2014;44:885-894.

80. Beauchamp MK, Janaudis-Ferreira T, Goldstein RS, Brooks D. Optimal duration of pulmonary rehabilitation for individuals with chronic obstructive pulmonary disease: a systematic review. Chron Respir Dis 2011;8:129-140.

81. Troosters T, Casaburi R, Gosselink R, Decramer M. Pulmonary rehabilitation in chronic obstructive pulmonary disease. Am J Respir Crit Care Med 2005;172:19-38. 
82. Foglio K, Bianchi L, Ambrosino N. Is it really useful to repeat outpatient pulmonary rehabilitation programs in patients with chronic airway obstruction? A 2-year controlled study. Chest 2001;119:1696-1704.

83. Meis JJ, Bosma CB, Spruit MA, Franssen FM, Janssen DJ, Teixeira PJ, Augustin IM, Wouters EF, de Vries NK, Schols AM, et al. A qualitative assessment of COPD patients' experiences of pulmonary rehabilitation and guidance by healthcare professionals. Respir Med 2014;108:500-510.

84. Zwerink M, Brusse-Keizer M, van der Valk PD, Zielhuis GA, Monninkhof EM, van der Palen J, Frith PA, Effing T. Self management for patients with chronic obstructive pulmonary disease. Cochrane Database Syst Rev 2014;3:CD002990.

85. Spencer LM, Alison JA, McKeough ZJ. Maintaining benefits following pulmonary rehabilitation: a randomised controlled trial. Eur Respir $\mathrm{J}$ 2010;35:571-577.

86. Johnston KN, Young M, Grimmer KA, Antic R, Frith PA. Barriers to, and facilitators for, referral to pulmonary rehabilitation in COPD patients from the perspective of Australian general practitioners: a qualitative study. Prim Care Respir J 2013;22:319-324.

87. Joint Royal Colleges of Physician Training Board. 2010 Respiratory medicine single CCT decision aid [accessed 2015 Oct 26]. Available from: http://www.jrcptb.org.uk/documents/2010-respiratorymedicine-single-cct-decision-aid-revised-2014

88. Accreditation Council for Graduate Medical Education. Program requirements for graduate medical education in pulmonary disease and critical care medicine (internal medicine). 2014 [accessed 2015 Oct 26]. Available from: https://www.acgme.org/acgmeweb/portals/0/pfassets/ 2013-pr-faq-pif/156_pulmonary_critical_care_int_med_07132013.pdf

89. Royal College of Physicians and Surgeons of Canada. Objectives of training in the subspecialty of adult respirology. 2011 [accessed 2015 Oct 26]. Available from: https://www.medicine.mcgill.ca/ postgrad/accreditation_2013/PSQs/2_Respirology_adult/ 05_OTR_Respirology_adult_2011.pdf

90. Besluit longziekten en tuberculose 1-januari-2013 (pdf) [accessed 2015 Oct 26]. Available from: http://knmg.artsennet.nl/Opleiding-enherregistratie/CGS/Regelgeving/Huidige-regelgeving/Longziekten-entuberculose.htm

91. Curricula [accessed 2015 Oct 26]. Available from: https:// members.racp.edu.au/page/advanced-curricula

92. Recommendations for the diagnosis and treatment of chronic obstructive pulmonary disease (COPD), April 2011 [in Spanish] [accessed 2015 Oct 26]. Available from: https://www.alatorax.org/ epoc/guia-epoc-alat/recomendaciones-para-el-diagnostico-ytratamiento-de-la-enfermedad-pulmonar-obstructiva-cronica-epocabril-2011

93. BTS. IMPRESS guide to pulmonary rehabilitation. 2011 [accessed 2015 Oct 26]. Available from: http://www.Impressresp.Com/ index.Php?Option=com_content\&view=article\&id=38:Pulmonaryrehabilitation\&catid $=17$ : Service-delivery\&itemid $=32$

94. Griffiths TL, Burr ML, Campbell IA, Lewis-Jenkins V, Mullins J, Shiels K, Turner-Lawlor PJ, Payne N, Newcombe RG, lonescu AA, et al. Results at 1 year of outpatient multidisciplinary pulmonary rehabilitation: a randomised controlled trial. Lancet 2000;355:362-368.

95. Griffiths TL, Phillips CJ, Davies S, Burr ML, Campbell IA. Cost effectiveness of an outpatient multidisciplinary pulmonary rehabilitation programme. Thorax 2001;56:779-784.

96. Zoumot Z, Jordan S, Hopkinson NS. Emphysema: time to say farewell to therapeutic nihilism. Thorax 2014;69:973-975.

97. BTS. IMPRESS guide to the relative value of COPD interventions: executive summary. 2012 [accessed 2015 Oct 26]. Available from: $\mathrm{http}: / /$ www.Impressresp.Com/index.Php?Option=com_docman\&task= doc_view\&gid $=52 \&$ itemid $=82$

98. California Pulmonary Rehabilitation Collaborative Group. Effects of pulmonary rehabilitation on dyspnea, quality of life, and healthcare costs in California. J Cardiopulm Rehabil 2004;24:52-62.

99. Raskin J, Spiegler P, McCusker C, ZuWallack R, Bernstein M, Busby J, DiLauro P, Griffiths K, Haggerty M, Hovey L, et al. The effect of pulmonary rehabilitation on healthcare utilization in chronic obstructive pulmonary disease: the Northeast Pulmonary Rehabilitation Consortium. J Cardiopulm Rehabil 2006;26:231-236.
100. Brooks D, Sottana R, Bell B, Hanna M, Laframboise L, Selvanayagarajah $\mathrm{S}$, Goldstein R. Characterization of pulmonary rehabilitation programs in Canada in 2005. Can Respir J 2007;14:87-92.

101. Collins EG, Bauldoff G, Carlin B, Crouch R, Emery CF, Garvey C, Hilling L, Limberg T, ZuWallack R, Nici L; American Association of Cardiovascular and Pulmonary Rehabilitation. Clinical competency guidelines for pulmonary rehabilitation professionals: position statement of the American Association of Cardiovascular and Pulmonary Rehabilitation. J Cardiopulm Rehabil Prev 2014;34: 291-302.

102. Rochester CL, Spanevello A. Heterogeneity of pulmonary rehabilitation: like apples and oranges - both healthy fruit. Eur Respir J 2014;43:1223-1226.

103. Sabit R, Griffiths TL, Watkins AJ, Evans W, Bolton CE, Shale DJ, Lewis KE. Predictors of poor attendance at an outpatient pulmonary rehabilitation programme. Respir Med 2008;102:819-824.

104. Arbane G, Tropman D, Jackson D, Garrod R. Evaluation of an early exercise intervention after thoracotomy for non-small cell lung cancer (NSCLC), effects on quality of life, muscle strength and exercise tolerance: randomised controlled trial. Lung Cancer 2011; 71:229-234.

105. Chin RC, Guenette JA, Cheng S, Raghavan N, Amornputtisathaporn $\mathrm{N}$, Cortés-Télles A, Webb KA, O'Donnell DE. Does the respiratory system limit exercise in mild chronic obstructive pulmonary disease? Am J Respir Crit Care Med 2013;187: 1315-1323.

106. Guenette JA, Jensen D, Webb KA, Ofir D, Raghavan N, O'Donnell DE. Sex differences in exertional dyspnea in patients with mild COPD: physiological mechanisms. Respir Physiol Neurobiol 2011;177: 218-227.

107. O'Donnell DE, Laveneziana P, Webb K, Neder JA. Chronic obstructive pulmonary disease: clinical integrative physiology. Clin Chest Med 2014;35:51-69.

108. Ofir D, Laveneziana P, Webb KA, Lam YM, O'Donnell DE. Mechanisms of dyspnea during cycle exercise in symptomatic patients with GOLD stage I chronic obstructive pulmonary disease. Am J Respir Crit Care Med 2008;177:622-629.

109. Orozco-Levi M, Coronell C, Ramírez-Sarmiento A, Lloreta J, MartínezLlorens J, Galdiz JB, Gea J. Injury of peripheral muscles in smokers with chronic obstructive pulmonary disease. Ultrastruct Pathol 2012;36:228-238.

110. Fastenau A, van Schayck OC, Gosselink R, Aretz KC, Muris JW. Discrepancy between functional exercise capacity and daily physical activity: a cross-sectional study in patients with mild to moderate COPD. Prim Care Respir J 2013;22:425-430.

111. Van Remoortel H, Hornikx M, Demeyer $H$, Langer D, Burtin $C$, Decramer M, Gosselink R, Janssens W, Troosters T. Daily physical activity in subjects with newly diagnosed COPD. Thorax 2013;68: 962-963.

112. Hayashi $Y$, Senjyu H, Iguchi A, Iwai S, Kanada R, Honda S, Ozawa H. Prevalence of depressive symptoms in Japanese male patients with chronic obstructive pulmonary disease. Psychiatry Clin Neurosci 2011;65:82-88.

113. Sin DD, Wu L, Man SF. The relationship between reduced lung function and cardiovascular mortality: a population-based study and a systematic review of the literature. Chest 2005;127: 1952-1959.

114. Hurst JR, Vestbo J, Anzueto A, Locantore N, Müllerova H, Tal-Singer R, Miller B, Lomas DA, Agusti A, Macnee W, et al.; Evaluation of COPD Longitudinally to Identify Predictive Surrogate Endpoints (ECLIPSE) Investigators. Susceptibility to exacerbation in chronic obstructive pulmonary disease. N Engl J Med 2010;363: 1128-1138.

115. García-Rio F, Soriano JB, Miravitlles M, Muñoz L, Duran-Tauleria E, Sánchez G, Sobradillo V, Ancochea J. Overdiagnosing subjects with COPD using the 0.7 fixed ratio: correlation with a poor healthrelated quality of life. Chest 2011;139:1072-1080.

116. Chee A, Sin DD. Treatment of mild chronic obstructive pulmonary disease. Int J Chron Obstruct Pulmon Dis 2008;3:563-573.

117. Jácome C, Marques A. Pulmonary rehabilitation for mild COPD: a systematic review. Respir Care 2014;59:588-594. 
118. Vogiatzis I, Terzis G, Stratakos G, Cherouveim E, Athanasopoulos D, Spetsioti S, Nasis I, Manta P, Roussos C, Zakynthinos S. Effect of pulmonary rehabilitation on peripheral muscle fiber remodeling in patients with COPD in GOLD stages II to IV. Chest 2011;140: 744-752.

119. Ries AL, Kaplan RM, Limberg TM, Prewitt LM. Effects of pulmonary rehabilitation on physiologic and psychosocial outcomes in patients with chronic obstructive pulmonary disease. Ann Intern Med 1995;122:823-832.

120. Seymour JM, Moore L, Jolley CJ, Ward K, Creasey J, Steier JS, Yung B, Man WD, Hart N, Polkey MI, et al. Outpatient pulmonary rehabilitation following acute exacerbations of COPD. Thorax 2010;65:423-428.

121. Cote CG, Dordelly LJ, Celli BR. Impact of COPD exacerbations on patient-centered outcomes. Chest 2007;131:696-704.

122. Kessler R, Ståhl E, Vogelmeier C, Haughney J, Trudeau E, Löfdahl CG, Partridge MR. Patient understanding, detection, and experience of COPD exacerbations: an observational, interview-based study. Chest 2006;130:133-142.

123. Pitta F, Troosters T, Probst VS, Spruit MA, Decramer M, Gosselink R. Physical activity and hospitalization for exacerbation of COPD. Chest 2006;129:536-544.

124. Demenzhandbuch [accessed 2015 Oct 26]. Available from: https:// static.uni-graz.at/fileadmin/Unikid-Unicare/Broschueren/ Demenzhandbuch.pdf

125. Australian Lung Foundation. Pulmonary Rehabilitation Toolkit [accessed 2015 Oct 26]. Available from: http://www. pulmonaryrehab.com.au/welcome.asp

126. Jenkins S, Hill K, Cecins NM. State of the art: how to set up a pulmonary rehabilitation program. Respirology 2010;15:1157-1173.

127. Garber CE, Blissmer B, Deschenes MR, Franklin BA, Lamonte MJ, Lee IM, Nieman DC, Swain DP; American College of Sports Medicine. American College of Sports Medicine position stand. Quantity and quality of exercise for developing and maintaining cardiorespiratory, musculoskeletal, and neuromotor fitness in apparently healthy adults: guidance for prescribing exercise. Med Sci Sports Exerc 2011;43:1334-1359.

128. American College of Sports Medicine. ACSM's guidelines for exercise testing and prescription. Philadelphia, PA: Lippincott Williams \& Wilkins; 2013.

129. Watz H, Pitta F, Rochester CL, Garcia-Aymerich J, ZuWallack R, Troosters T, Vaes AW, Puhan MA, Jehn M, Polkey MI, et al. An official European Respiratory Society statement on physical activity in COPD. Eur Respir J 2014;44:1521-1537.

130. Spruit MA, Augustin IM, Vanfleteren L, Janssen DJ, Gaffron S, Pennings HJ, Smeenk F, Pieters W, van den Bergh JJ, Michels AJ, et al. Differential response to pulmonary rehabilitation in COPD: multidimensional profiling. Eur Respir $J$ [online ahead of print] 9 Oct 2015; DOI: 10.1183/13993003.00350-2015.

131. Ringbaek T, Brondum E, Martinez G, Thogersen J, Lange P. Longterm effects of 1-year maintenance training on physical functioning and health status in patients with COPD: a randomized controlled study. J Cardiopulm Rehabil Prev 2010;30:47-52.

132. Holland AE, Hill CJ, Rochford P, Fiore J, Berlowitz DJ, McDonald CF. Telerehabilitation for people with chronic obstructive pulmonary disease: feasibility of a simple, real time model of supervised exercise training. J Telemed Telecare 2013;19:222-226.

133. Stickland M, Jourdain T, Wong EY, Rodgers WM, Jendzjowsky NG, Macdonald GF. Using Telehealth technology to deliver pulmonary rehabilitation in chronic obstructive pulmonary disease patients. Can Respir J 2011;18:216-220.

134. Tousignant M, Marquis N, Pagé C, Imukuze N, Métivier A, St-Onge V, Tremblay A. In-home telerehabilitation for older persons with chronic obstructive pulmonary disease: a pilot study. Int $J$ Telerehabil 2012;4:7-14.

135. Goldstein RS, O'Hoski S. Telemedicine in COPD: time to pause. Chest 2014;145:945-949.

136. Maltais F, Bourbeau J, Shapiro S, Lacasse $Y$, Perrault $H$, Baltzan $M$, Hernandez P, Rouleau M, Julien M, Parenteau S, et al.; Chronic Obstructive Pulmonary Disease Axis of Respiratory Health Network, Fonds de recherche en santé du Québec. Effects of home-based pulmonary rehabilitation in patients with chronic obstructive pulmonary disease: a randomized trial. Ann Intern Med 2008;149:869-878.

137. Pradella CO, Belmonte GM, Maia MN, Delgado CS, Luise AP, Nascimento OA, Gazzotti MR, Jardim JR. Home-based pulmonary rehabilitation for subjects with COPD: a randomized study. Respir Care 2015;60:526-532.

138. Ramos EM, de Toledo-Arruda AC, Fosco LC, Bonfim R, Bertolini GN, Guarnier FA, Cecchini R, Pastre CM, Langer D, Gosselink R, et al. The effects of elastic tubing-based resistance training compared with conventional resistance training in patients with moderate chronic obstructive pulmonary disease: a randomized clinical trial. Clin Rehabil 2014;28:1096-1106.

139. ClinicalTrials.gov [accessed 2015 Oct 26]. Available from: https:// clinicaltrials.gov/ct2/show/NCT01423227

140. Lacasse Y, Goldstein R, Lasserson TJ, Martin S. Pulmonary rehabilitation for chronic obstructive pulmonary disease. Cochrane Database Syst Rev 2006;4:CD003793.

141. Laviolette L, Bourbeau J, Bernard S, Lacasse Y, Pepin V, Breton MJ, Baltzan M, Rouleau M, Maltais F. Assessing the impact of pulmonary rehabilitation on functional status in COPD. Thorax 2008;63:115-121. 